\title{
Regional Disparities and Regional Development: The Case of Serbia ${ }^{1)}$
}

Emilija Manić, Svetlana Popović, Dejan Molnar, all Belgrade [Beograd]* with 6 Fig. and 2 Tab. in the text

\section{Contents}

Zusammenfassung 191

Summary

1 Introduction

192

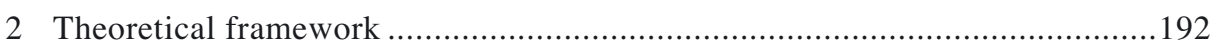

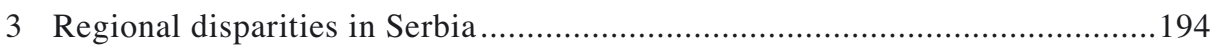

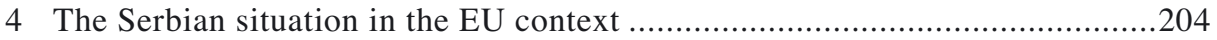

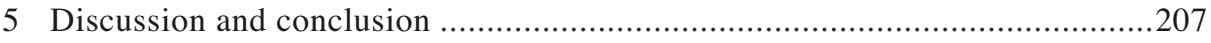

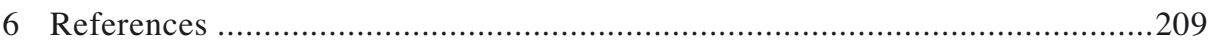

\section{Zusammenfassung}

Regionale Disparitäten und Regionalentwicklung: der Fall Serbiens

Der Artikel befasst sich mit regionalen Disparitäten in Serbien, wobei demographische und wirtschaftliche Unterschiede berücksichtigt und mit Mitgliedsländern der EU und Nachbarländern verglichen werden. Das Maß der regionalen Disparitäten Serbiens wird mit statistischen Instrumentarien erfasst und kartographisch visualisiert. Anhand der Ergebnisse werden Lösungskonzepte für Serbien vorgeschlagen, wobei Entwicklungsstrategien Serbiens und der EU berücksichtigt werden.

\footnotetext{
1) The executive editor of this journal as well as the Austrian Geographical Society wish to remark that they do not share the views expressed in this article (including its maps) on the legal status of Kosova/ Kosovo and that this view is also not shared by the Austrian government as well as by the governments of the vast majority of EU member states.

* Emilija Manić, PhD, Svetlana Popović, Msc, Dejan Molnar, Msc, Faculty of Economics, University of Belgrade, Kamenicka 6, 11000 Beograd, Serbia; e-mail: geografija@ekof.bg.ac.rs, ceca@ekof.bg.ac. rs, http://www.ekof.bg.ac.rs, molnar.dejan@gmail.com,www.ekof.bg.ac.rs
} 


\section{Summary}

The paper deals with regional disparities in Serbia, considering demographic and economic regional differences. The analyses of those disparities are placed in the context of the EU and of neighboring countries. The authors used statistical instruments to show the extent of Serbian regional disparities, as well as maps to visualise these differences. The results are used to develop a rough outline of possible solutions to such regional inequalities in Serbia, considering existing Serbian and EU development documents.

\section{Introduction}

Regional inequality is a salient feature of many countries, both developed and developing. For example, the GDP per capita in London is much larger than in the United States, while in Wales it is lower than in Greece. Mississippi (USA) has a GDP per person closer to Slovenia than to many US states, while people in the District of Columbia or Delaware have a higher GDP per capita than most OECD countries. There are many different studies devoted to regional inequalities analysis and considerations of its roots and consequences (YemTsov 2003; B ADDELEY 2006; KIM 2008; Duro 2004; Ezcurra 2007; Hofer \& Wörgötter 1997; Barrios \& Strobl 2006; Magrini 1999; Petrakos 2001; Petrakos \& Saratsis 2000; Rodrigues-Oreggia 2005; Terrasi 1999; WANG \& GE 2004).

The aim of this paper is to show regional disparities in Serbia, both demographic and economic, and to compare them to the neighbouring and European Union (EU) context. All the research was conducted within the theoretical framework of the existing paradigm shift in regional development policy using knowledge of geography and economics. It is very rare to find a project in which both geographers and economists collaborate in order to outline possible solutions for problems in the area of unbalanced regional development as it is done in this case.

\section{Theoretical framework}

Theoretical explanations for regional disparities are typically based on several different theories: growth theory (BARRO \& SALA-I-MARTIN 1995), New Economic Geography (Krugman 1998; Fujita, Krugman \& Venables 1999; Krugman \& Livas 1996; VenABLes 2011), but also some new theories rooted in the area of evolutionary economic geography (McCANn \& V An OORT 2009; Boschma \& Frenken 2011). According to growth theory, regional inequality tends to rise as growth occurs in discrete locales, but later on inequalities will decline as equilibrating forces such as better infrastructure, technological diffusion, decreasing returns to capital in richer and high-wage areas, and the diseconomies of agglomeration become stronger (WILLIAMSON 1965). 
A different view has been proposed more recently within the context of the New Economic Geography school and endogenous growth (ROMER 1986; LuCAS 1988; FISHER 2006; Fingleton 2011), who argue that increasing returns to scale and the advantages of agglomeration of capital and knowledge will tend to perpetuate, or even increase spatial inequalities.

If we take into account the European experience of existing problems related to balancing regional development, regionalisation is seen as the preferred form of vertical organisation of government (state organisation) for three predominant reasons: (i) functional, (ii) economic and (iii) recognitional. However, one should bear in mind that this process represents an opportunity, but not an absolute guarantee.

In Europe, regional development became a relevant topic for policy makers in the 1950 s and 1960s. The main objective of regional development policy was to achieve more equity and sustainable growth. The main instruments were the redistribution of wealth in the form of centrally controlled financial transfers and wide-scale public investments. Although this was a period of relatively strong economic growth, fiscal expansion and high employment, several regions were confronted with structural changes in dominant sectors (agriculture, specific industries, etc.). During the 1970s and early 1980s regional development policies were adapted to new challenges, focusing on reducing disparities in income and infrastructure and on activities of a social nature. Early adopters were those countries facing substantial regional disparities (e.g. the United Kingdom, France, Italy, Sweden) and later a major push came from the European level (EU Cohesion Policy, starting from 1988).

Many international and European studies have shown that the regional development policy models applied during the 1980s have produced rather disappointing results, mainly due to the slow convergence of lagging regions (BARRo \& SALA-I-MARTiN 1991; BoldRIN \& CANOva 2001). The centrally managed redistribution of subsidies to less developed areas resulted in an excessive dispersal of funds, thereby weakening the effect of the scale of public intervention, which was ultimately unable to produce measurable effects for development and resulted in even bigger lagging of undeveloped regions across the EU (Pike, RodRiguez-Pose \& TomAney 2006).

In the 1990s the disappointing results on convergence became the motivation for changing the paradigm of regional policy in relation to the objectives, priorities, tools, actors, and territorial areas of intervention (CAPELLO 2009). Regional development policy has evolved from a model of short-term grants distributed following orders from a central government authority to a model of long-term, decentralised development policies aimed at promoting growth in all regions (irrespective of the degree of prosperity) - from dispersed intervention to more selective investments. Development strategies have begun to focus on endogenous territorial characteristics (instead of exogenous investments and transfers). Various publications therefore suggest that development policies should support growth in all regions, and regions should invest into their own development by mobilising local resources and funds in order to exploit their specific comparative advantages without excessive reliance on national transfers and grants (OECD 2009; B ARCA 2009; STIMSON et al. 2011). 
Over the past decades, many EU-member states have changed the balance between sectoral and more integrated policies. At the same time, changes have taken place regarding the involvement of regional and local governments in policy design and implementation. This new concept connects three main elements: (i) the place-specificity of natural and institutional resources and of individual preferences and knowledge, (ii) the role played by the (material and immaterial) linkages between places, and (iii) the resulting need for interventions to be tailored to places. This concept is built upon the new paradigm of development policy whose main features are based on tailoring interventions to specific territorial contexts and their spatial linkages, and mobilising and aggregating the knowledge and preferences of local actors (BARCA 2009). Support for regional development policy is therefore the development of internal growth factors, and not merely the redistribution of revenue to less developed areas of the country (CAMAGNI 2009). It was clear that development of place cannot be a solely top-down or bottom-up approach, but a multi-governance approach for regional development policy in a European perspective.

Whether a sectorally or territorially more integrated approach for developing regions will have preference depends largely on the type of policy, the regional conditions and the existing institutional capacity.

\section{Regional disparities in Serbia}

\subsection{Area of study and methodological issues}

The Republic of Serbia, according to its constitution, consists of two autonomous provinces [autonomna pokraijna], 2) i.e. Vojvodina [Autonomna Pokraijna Vojvodina] as well as Kosovo and Metohija [Autonomna Pokraijna Kosovo i Metohija], ${ }^{3)}$ and the territory outside these provinces is called Serbia Proper [Uža Srbija]. This kind of territorial organisation is an asymmetric one and over time it has proved to be one of the serious obstacles in transferring jurisdiction from the central to the provincial or district level. This regionalisation in Serbia has its roots in the period when Serbia was a constitutive unit of federal Yugoslavia. A regional issue in former Yugoslavia has never had adequate importance in the hierarchy of economic and social goals. As a consequence of this regionalisation, development goals were based on political instead of economic grounds. Former Yugoslavia had six constitutive republics and two provinces and they aspired to establish their own, as much as it was possible, independent

\footnotetext{
2) The official term in Serbian language is here and in consequent cases given in the nominative singular form.

3) The Autonomous Province of Kosovo and Metohija (K\&M) $\left(10,887 \mathrm{~km}^{2}\right)$ has been under the UN administration of UNMIK since June 1999. Serbia has no authority over this territory and it could not conduct the 2002 census there, so the national statistical office does not have any reliable data about K\&M. In February 2008 this autonomous province declared its independence, which has been recognized by a certain number of countries in the world ( 87 by February 2012), but not by Serbia and the United Nations
} 
economic structure, production and infrastructure capacities. All that made the system very inefficient and regionalisation dysfunctional (Ocić 1998, Minailović 1990).

By the Law on Territorial Organisation (Službeni glasnik RS 129-07 2007), Serbia has been divided into 150 municipalities [opština] and 23 towns [grad]. These 174 units of local government have legal authority and are able to perform certain administrative duties which the central government transferred to them. However, by the Law on State Administration (Službeni glasnik RS 79-05 2005) 29 administrative districts [okrug] have also been constituted. These districts consist of several municipalities, but are not self-governing and represent just deconcentrated state administration. The so far last territorial re-organisation was implemented in 2010 by the Law on Regional Development (Službeni glasnik RS 51/09 2010), which introduced so-called "statistical regions" - Serbia-North [Srbija-Sever] and Serbia-South [Srbija-Jug] on the NUTS-1 level as well as five regions at the NUTS-2 level: Vojvodina, the Belgrade Region [Beogradski region], Šumadija and West Serbia [Šumadija i Zapadna Srbija], South and East Serbia [Južna i Istočna Srbija] and Kosovo and Metohija [Kosovo i Metohija]).

During our analysis of spatial socio-economic disparities in Serbia we faced several methodological problems. Firstly, regional statistics in Serbia are really poor. Data on GDP, e.g., are available at the regional level only for the last two years. There are no continuous time series due to methodological changes and the established economic development indicators on the municipality level.

Secondly, the GDP can hardly be allocated. Although many firms are registered in Belgrade [Beograd], their production is located in other regions, and there exist also different price levels for some goods. Prices are higher in Belgrade, Novi Sad and other cities, which make their GDP larger than in the case of using the Purchase Power Parity (PPP) methodology.

Available data were taken from the National Statistical Office [Statistički zavod Republike Srbije] - the 2002 census and the first results of the 2011 census as well as from periodical statistics - and were analysed through ArcGIS software and some statistical instruments (max-min ratio as a measure of dispersion) for different spatial levels (NUTS-2 and NUTS-3).

\subsection{Demographic disparities}

According to the 2011 census (first results) Serbia has 7,120,666 inhabitants, which is a number 377,000 smaller than documented by the 2002 census (STATISTIČKI Zavod Republike SRbije 2011). The main reason for this decline is a negative natural population development all over the country (from $0.2 \%$ in 1991 to $-4.6 \%$ in 2008).

The heaviest population decrease was recorded in eastern and southern Serbia, were population decreases already for a long time. Only three areas in Serbia documented a population increase: Belgrade and Novi Sad due to a positive net-migration rate as well as the municipality of Novi Pazar due to a long-term positive natural increase of the Muslim group inhabiting this commune. Thus, the Serbian population is characterised by a depopulation process, an accelerated process of demographic ageing and migration within the context of huge regional demographic inequalities. 


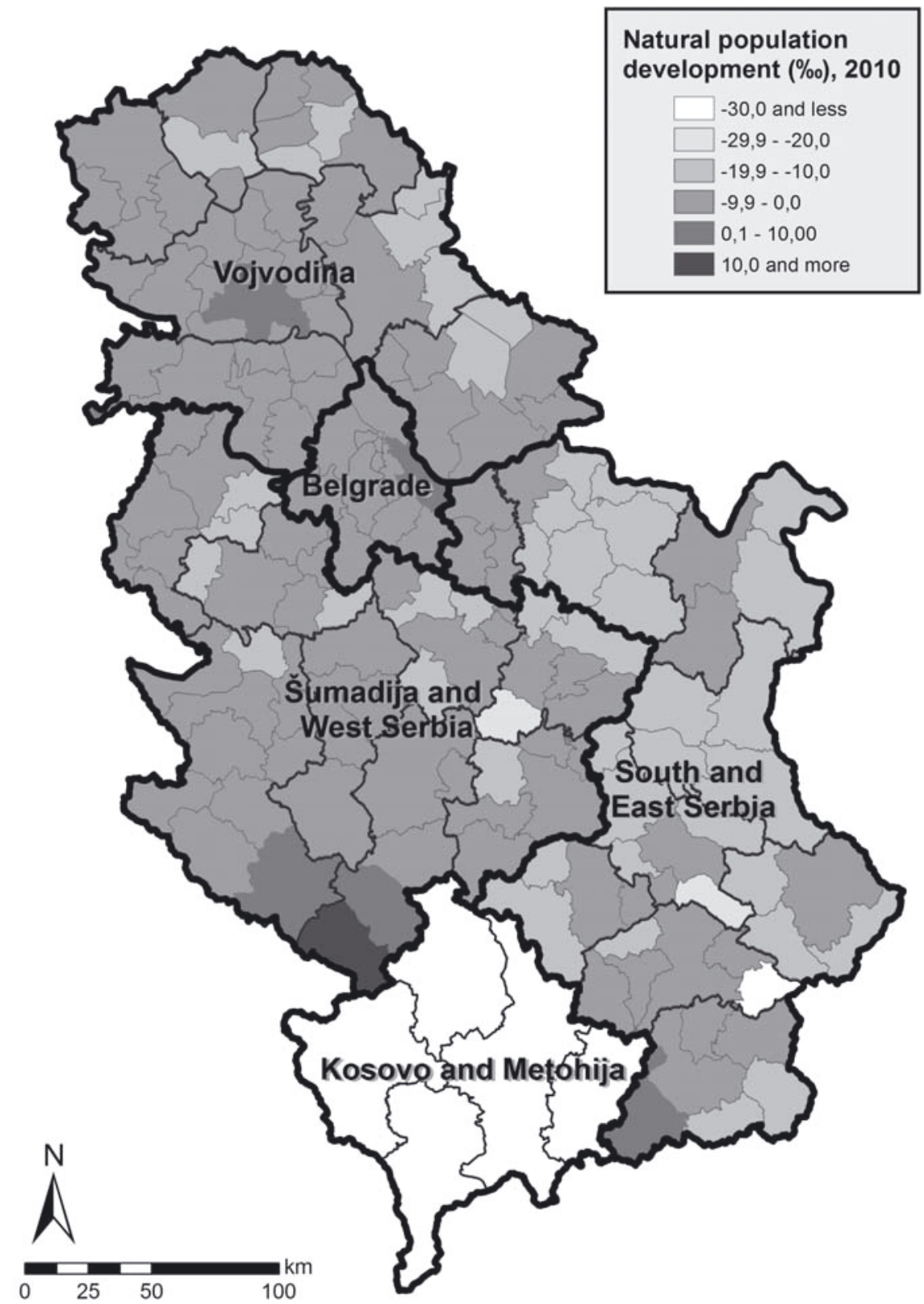

Source: StatističKi zavod Republike Srbije 2012; own analysis. No data for Kosovo and Metohija available.

Fig. 1: Natural population development 20104)

4) See footnote 1). 


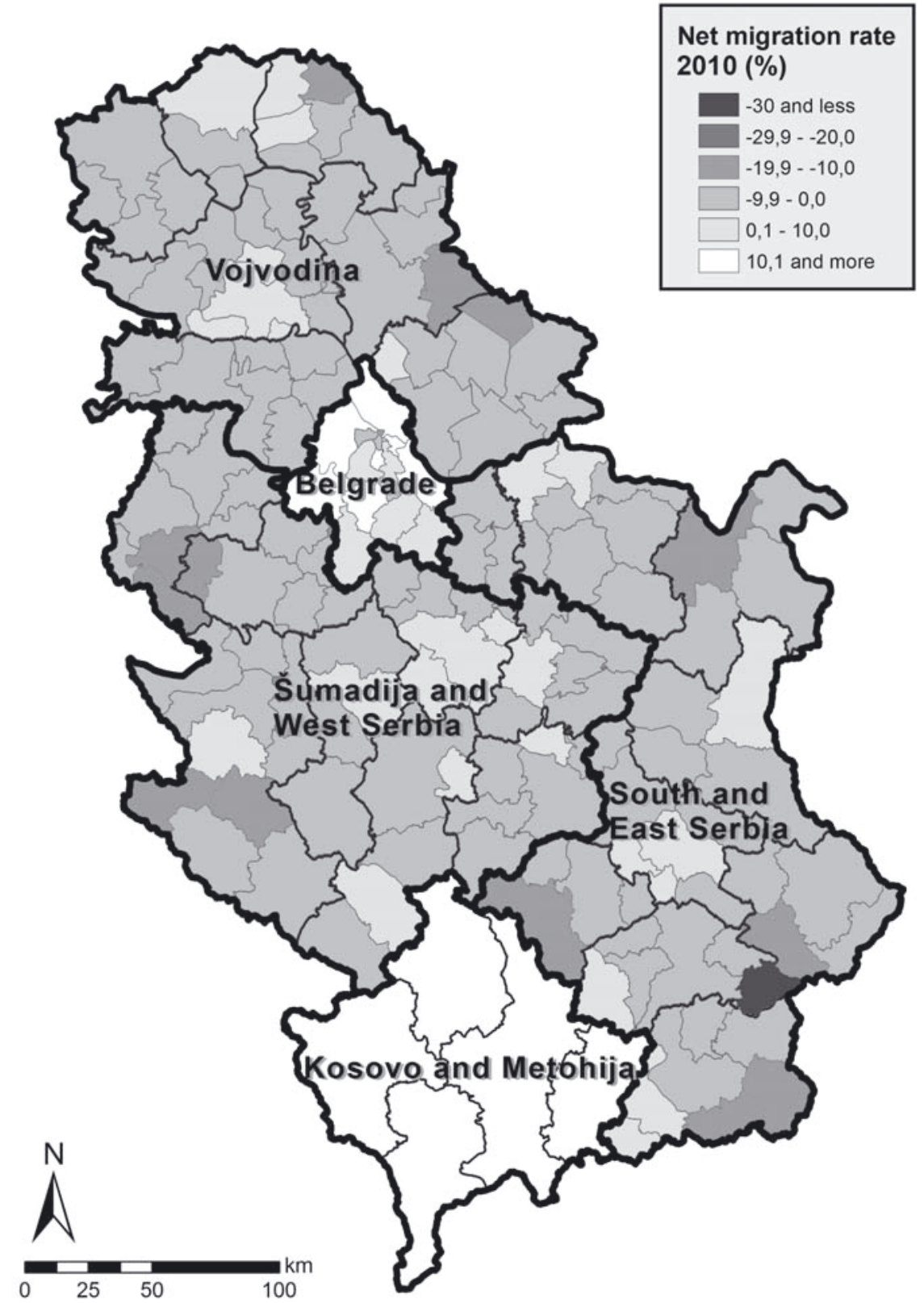

Source: StatističKi zavod Republike Srbije 2012; own analysis. No data for Kosovo and Metohija available.

Fig. 2: Net migration rate $2010^{5 \text { ) }}$

5) See footnote 1) 
If we analyse the demographic inequalities at municipality level, it becomes evident that they are considerable (see Fig. 1).

Vojvodina shows significant spatial variations in the natural population development rate at municipality level. Novi Sad, e.g., has a natural increase, but peripheral municipalities in the East and North show very negative figures, between $-10 \%$ and $-20 \%$ ).

However, the worst situation occurs in East and South Serbia, where only two municipalities with a Muslim Albanian population majority record a natural increase (Bujanovac 1.9\%o and Preševo 3.1\%o), while the largest number shows negative figures (usually over $-10 \%$ with extremes such as Crna Trava $-47.1 \%$ or Gadzin Han $-20.5 \%$ ).

Regional inequalities in ageing and demographic trends result from continued migration (see Fig. 2).

If we set aside migration caused by war in the ex-Yugoslavian areas (refugees from war-affected areas, internally displaced people), the heaviest migration flows in Serbia occurred from rural towards urban areas, from the South towards the North of Serbia and from all over Serbia to the Belgrade Region.

Compared to the results of the previous population census in 2002, the highest negative net-migration rates were recorded in the border municipalities of Serbia, i.e. in the eastern part of the Vojvodina, the East and South of the East and South Serbia Region, the West of Šumadija and the West Serbia Region (between -10\% and -20\%). It is evident that mainly young people and women are leaving these municipalities, so that the population that is left behind is not able to achieve population reproduction.

Besides the unsatisfactory age and gender structure in Serbia and the obvious regional disparities, the educational structure of the population is also very weak.

Serbia in general has a very small share of high-educated people (around 5\%). But the lowest shares show significant concordance with municipalities recording a population decline due to a negative natural development and net-migration rate. Regional analysis reveals heavy regional disparities with this indicator. University locations such as Belgrade, Novi Sad, Subotica, Kragujevac and Niš have the highest shares of high-educated people promoting economic development and increasing existing disparities. Less developed municipalities and regions, in contrast, have no chance to produce this human capital that could help them to escape their deplorable situation.

\subsection{Economic disparities}

Serbia is characterised by distinct differences in economic development between regions (NUTS-2 level) and municipalities (NUTS-3 level). Spatial analysis confirms high regional disparities at all levels in employment, economic activity and population density.

Regional and intraregional inequalities in Serbia are officially presented as "undeveloped areas", "developed centres" and "insufficiently developed peripheries" 


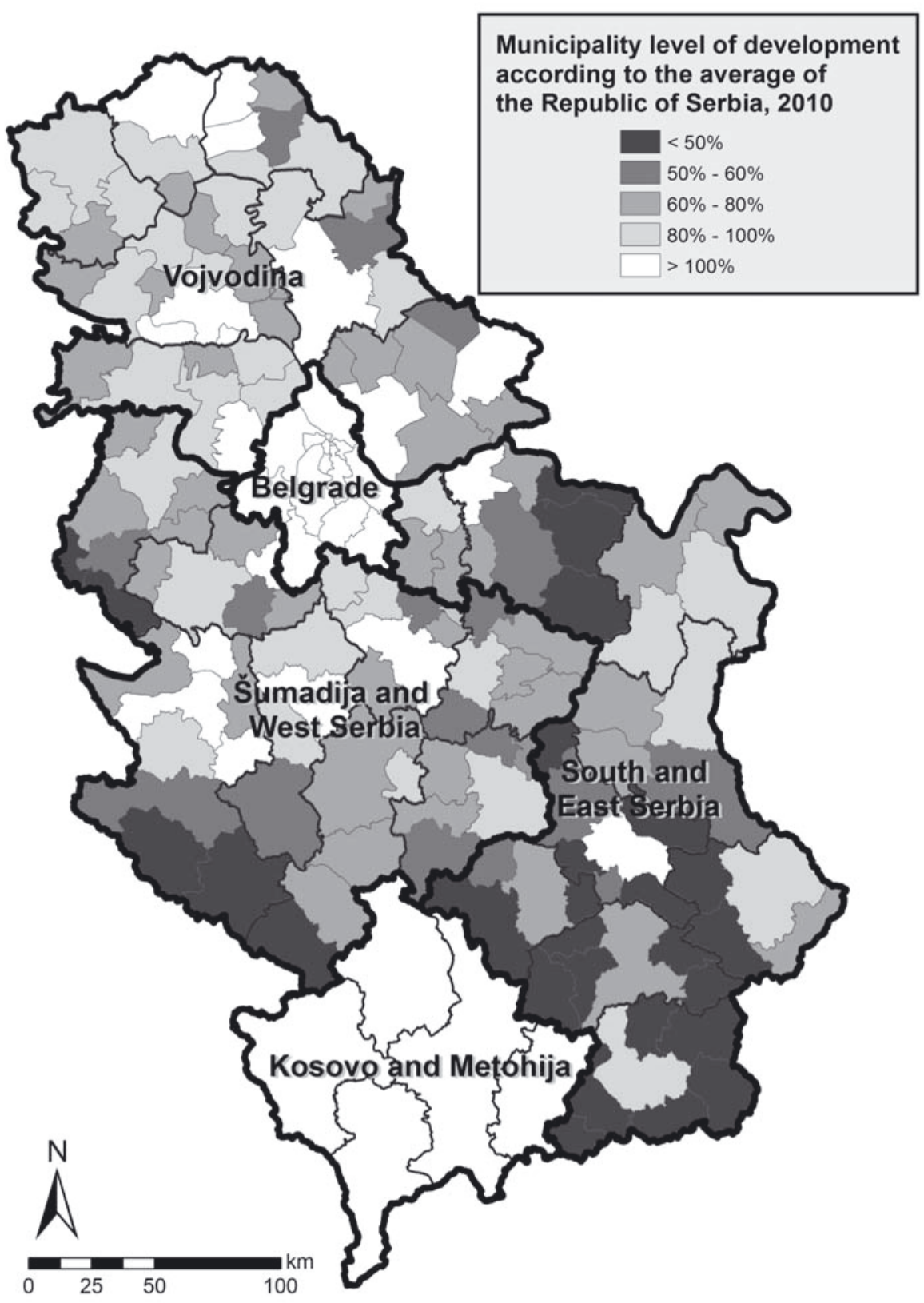

Source: StatističKi Zavod Republike Srbije 2012; own analysis.

Fig. 3: Level of development by municipalities compared to the average of Serbia, $2010^{6)}$

6) See footnote 1) 
(REPUBLIČKI ZAVOD ZA RAZVOJ 2009, 2010) and documented in the unified development list of regions and local territorial units (municipalities) (Službeni glasnik RS 69-11 2011). This list classifies municipalities either as "areas with a development level above the national average" (19 municipalities), "areas with a development level of $80-100 \%$ of the national average" (33 municipalities), "insufficiently developed areas with a development level of $60-80 \%$ of the national average" (47 municipalities), "undeveloped areas with a development level below $60 \%$ of the national average" (46 municipalities) and "devastated areas with a development level below $50 \%$ of the national average” (27 municipalities) (see Fig. 3).

When Gross Domestic Product (GDP) as one of the key economic indicators is analysed at the NUTS-2 level, the Belgrade Region has the largest portion of Serbia's GDP $(40 \%)$ and is positioned as the only developed region in Serbia, while all other regions are below the national average: Vojvodina 26\%, Šumadija and West Serbia $19.5 \%$, South and East Serbia 14.5\%. GDP per capita shows the same picture: The Belgrade Region has $180 \%$ of the national average, Vojvodina 95\%, while the other two regions are significantly underdeveloped (South and West Serbia 63\%, Šumadija and West Serbia 71\%).

The Belgrade Region has the highest share in total Serbian output according to Gross Value Added (GVA $)^{7)}$ - more than four times higher than the South and East Serbia Region.

As shown by the max/min ratio, the regions are not at the same level. In the Southern Bachka District [Južnobački distrikt] (Vojvodina), which is the most developed, production is more than six times higher than in the least developed Northern Banat District [Severnobanatski distrikt]. Similar differences exist in the South and East Serbia Region, while in the Šumadija and West Serbia Region the differences are not as big.

As regards employment, one third of the total number of employed persons in Serbia work in the Belgrade Region and only $18 \%$ are employed in South and East Serbia.

Taking into account demographic disparities, the number of employees per 1,000 inhabitants is a more reliable indicator of regional inequalities. However, the proportion remains the same: The Belgrade Region has the highest "density" of jobs, the lowest South and East Serbia.

The $\mathrm{max} / \mathrm{min}$ ratio of the number of employed persons at district level shows significant differences, but those at municipality level are even larger (see Fig. 4a). It is interesting to note that one of the highest disparities exists within the Belgrade Region: The max/min ratio between the Belgrade municipalities is 13.6; in the Gročka municipality only 143 persons per 1,000 inhabitants are employed, in Savski Venac they amount to 1,940 .

\footnotetext{
7) GVA is used to measure the Gross Regional Domestic Product and other measures of the output of areas smaller than the whole economy. It is defined as the value of output minus the value of intermediate consumption.
} 




Source: StatističKi Zavod Republike SRbije 2011b; own analysis.

Fig. 4a: Regional and intra-regional economic disparities, 2010 




Sources: StatističKi Zavod Republike Srbije 2011, 2012; own analysis.

Fig. 4b: Regional and intra-regional economic disparities, 2010 
This result is confirmed by the average salary. In the Belgrade Region it is $124 \%$ of the average salary in Serbia, in Vojvodina close to the national average, while in the other two regions it is only about $85 \%$ of the national average. The largest intraregional differences occur in South and East Serbia (max/min ratio 1.4), followed by Vojvodina (1.2).

At municipal level the differences are again larger: In South and East Serbia employees in Požarevac earn on average 2.3 times more than those in Vladičin Han; in the Belgrade Region and in Šumadija and West Serbia the max/min ratio is 2.1. The smallest differences are to be found among the Vojvodina municipalities, with a ratio of 1.8 .

The Belgrade Region has the highest budget income, but also the highest expenditure per capita - almost two times the average for Serbia. Vojvodina is below the average (around $80 \%$ ), and the other two regions are considerably below the Serbian average (slightly above $60 \%$ ). The differences between municipalities within the same region are larger than between districts. The largest differences occur among the Belgrade Region municipalities, those in the Vojvodina are smaller, whereas slightly larger differences exist in the other two regions.

Another indicator which confirms regional economic disparities in Serbia is investment into new fixed assets. As the most developed region in Serbia, the Belgrade Region accumulated more investment into fixed assets than the other three regions together. Slightly less than one quarter of total investment went to Vojvodina, 15\% to Šumadija and West Serbia and only $10 \%$ to South and East Serbia. The majority of acquired investment was used for the reconstruction and maintenance of existing equipment.

Intraregional disparities are even more sizeable: the Southern Bachka District [Južnobački district] attracted 13 times more investment than the Western Bachka District [Zapadnobački district] (Vojvodina). In Šumadija and West Serbia the max/ min ratio is lower (3.6) and in South and East Serbia it is 11.7. With the exception of the Belgrade Region the differences at the level of municipalities are enormous. In South and East Serbia the max/min ratio is almost 2,500, and in Vojvodina it is close to 2,300. This means that although there are municipalities that attract investors, these are mainly the already developed municipalities (see Fig. 4b).

Investment flow indicates the number of firms opened, more precisely the number of inhabitants per firm. In the least developed region of South and East Serbia there are almost twice as many inhabitants per firm than in the Belgrade Region, while in the other two regions this ratio is close to 1.4.

At district level the highest differences occur in Vojvodina, where the ratio is almost 1.8 compared to 1.3 in Šmadija and West Serbia and 1.4 in East and South Serbia.

Regional socio-economic disparities in Serbia are huge, but it seems that their size can only be seen objectively if we put them into an international or at least a broader regional context. 


\section{The Serbian situation in the EU context}

In the European context, Serbia as a whole is considerably lagging behind in socioeconomic terms. Serbia is classified as a medium-sized country in terms of area and population. The provisional ranking in the EU27 is 16, respectively 17 . However, in terms of size of economy and market, it should be classified as a small economy. With $0.3 \%$ of the EU27 GDP it ranks $23^{\text {rd }}$ within the EU27 and holds the $27^{\text {th }}$ position in entire Europe (out of 34 countries).

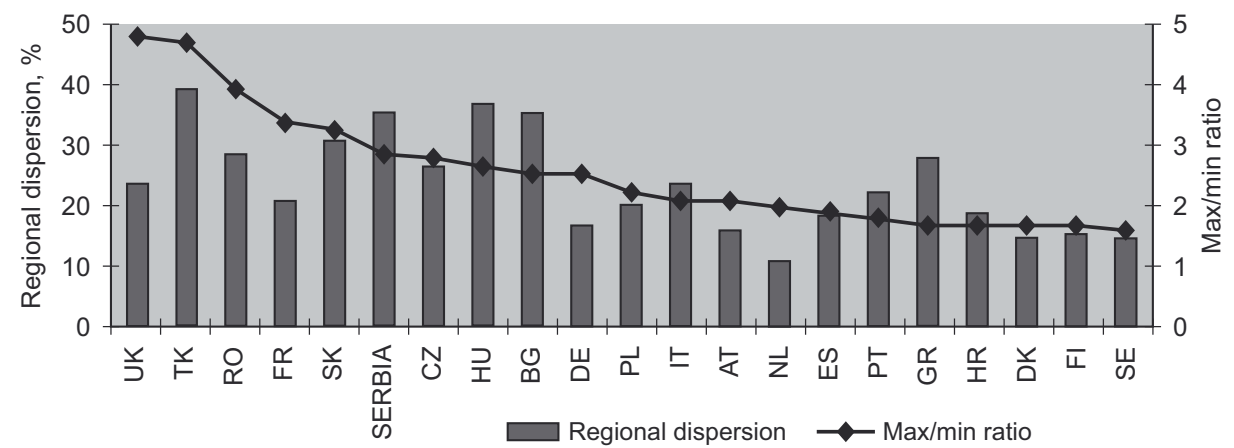

Source: Ministarstvo za exonomiju i Regionalni Razvoj Republike Srbije 2011.

Fig. 5: Regional dispersion of GDP per capita (on the NUTS-2 level) in EU member states and candidate countries, 2009

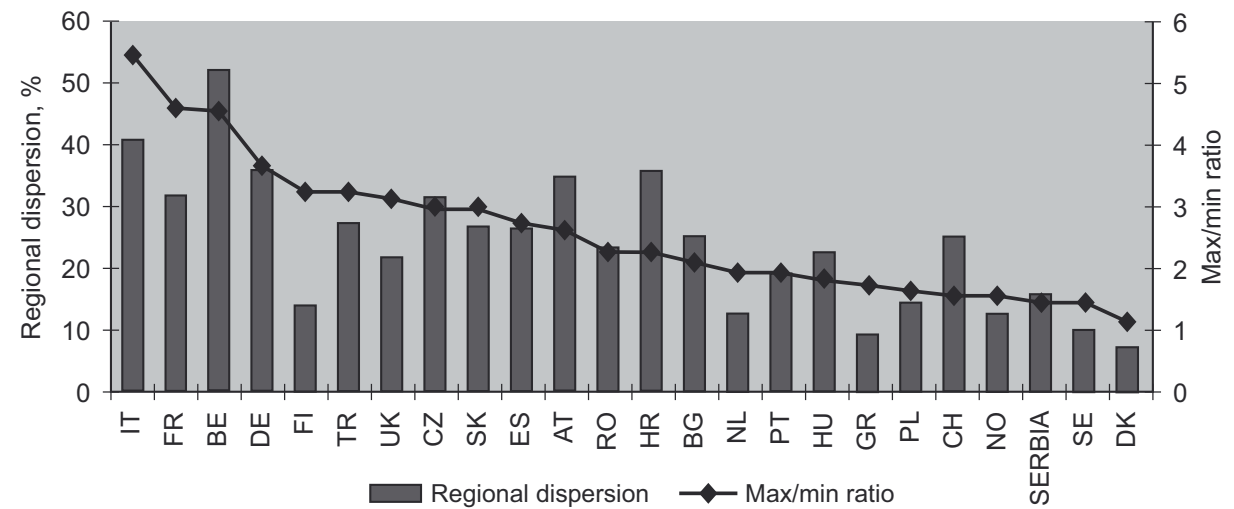

Source: Ministarstvo za ekonomiju i Regionalni Razvoj Republike Srbije 2011.

Fig. 6: Regional differentiation of unemployment (on the NUTS-2 level) in EU members and candidates, 2010 
Regional differentiation of GDP per capita in Serbia is high, but not exceptional in comparison with $20 \mathrm{EU}$ member states and candidate countries (see Fig. 5). On the $\max / \mathrm{min}$ ratio Serbia ranks $6^{\text {th }}$ after the United Kingdom, Turkey, Romania, France and Slovakia. But in regional dispersion of the GDP per capita ${ }^{8)}$ the position of Serbia is worse: Serbia ranks $3^{\text {rd }}$ after Hungary and very close to Bulgaria (see Fig. 5).

Compared to $23 \mathrm{EU}$ members and candidates, regional differentiation of unemployment is in Serbia low to moderate (see Fig. 6).

On the $\mathrm{max} / \mathrm{min}$ ratio Serbia is $22^{\text {nd }}$ and similar to Norway, Sweden and Switzerland and slightly above Denmark. However, in terms of regional dispersion the position of Serbia is worse $-17^{\text {th }}(15.9)$, similar to Greece, half of Croatia (>30) and significantly below Turkey and Bulgaria (25-27).

Gaps in economic development between Serbia and the EU27 are much larger. GDP per capita is 2.7 times lower than the EU27 average (below all other member states), export orientation is twice as low, labour productivity 3.4 times, investment per person employed 5.3 and investment per inhabitant 9 times lower (see Table 1).

Labour market indicators also reveal huge gaps. Employment rate and female employment rate are around 1.5 times lower than in the EU27 and are among the lowest of all countries ( $28^{\text {th }}$ in both cases).

Gaps in transport infrastructure endowment are also significant: The total road density is 1.6 times lower the EU average and positions Serbia in the $20^{\text {th }}$ place among 25 countries.

While Serbia appears to be similar to most of her neighbouring countries in terms of development level, there are significant gaps to more developed countries. In many cases these disparities may even overshadow the internal regional disparities. Most pronounced are gaps in economic development and structure, labour market, educational status of the population and transport infrastructure.

However, also the position of Serbia's regions compared to other European regions (NUTS-2) according to some key indicators (population density, GDP per capita, unemployment rate) is unfavourable (see Table 2). Among the EU27's 271 NUTS-2 regions Serbian regions figure almost at the very bottom.

Regional disparities in Serbia are often emphasised in Serbian economic policy and analytical documents, so they are expected to have significant implications for policy decisions and actions. However, solutions for such huge regional disparities are not easy to be found, primarily because specific circumstances within each region require a specific approach as well as combined top-down and bottom-up activities in regional policy.

\footnotetext{
8) Dispersion of regional GDP is defined as the sum of absolute differences between regional and national GDP per inhabitant, weighted on the basis of the regional share of population and expressed as a percentage of the national GDP per inhabitant. The value of the dispersion of the GDP per inhabitant is zero, if the values of regional GDP per inhabitant are identical in all regions of the country.
} 


\begin{tabular}{|c|c|c|c|c|c|c|c|c|}
\hline & & & & & & $\begin{array}{l}\text { UTS-2 } \\
\text { EU } 27\end{array}$ & $\begin{array}{l}\text { regio } \\
=100\end{array}$ & \\
\hline & 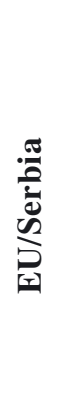 & 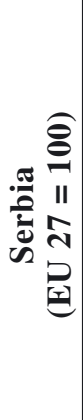 & 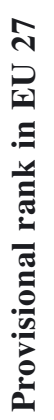 & 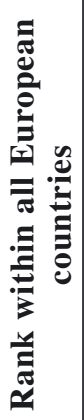 & 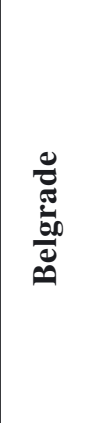 &  & 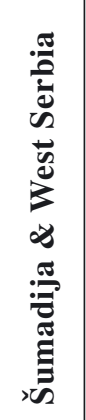 &  \\
\hline Area in sq.km (2010) & & $1.8 \%$ & 16 & 16 & & & & \\
\hline Population (2010) & & $1.5 \%$ & 17 & 23 & & & & \\
\hline $\begin{array}{l}\text { GDP at market prices, million EUR } \\
\text { (2009) }\end{array}$ & & $0.3 \%$ & 23 & 27 & & & & \\
\hline $\begin{array}{l}\text { Population density, inh./sq.km } \\
\text { (2010) }\end{array}$ & 1.2 & $83 \%$ & 17 & 18 & $449 \%$ & $80 \%$ & $68 \%$ & $56 \%$ \\
\hline GDP per capita, EUR PPS (2009) & 2.7 & $37 \%$ & 28 & 33 & $66 \%$ & $35 \%$ & $26 \%$ & $23 \%$ \\
\hline Export, \% of GDP (2009) & & $53 \%$ & 27 & 41 & $37 \%$ & $73 \%$ & $53 \%$ & $61 \%$ \\
\hline $\begin{array}{l}\text { Labour productivity, GDP at market } \\
\text { prices/empl. (2009) }\end{array}$ & 3.4 & $29 \%$ & 26 & 31 & $36 \%$ & $29 \%$ & $25 \%$ & $24 \%$ \\
\hline $\begin{array}{l}\text { Investment into new fixed assets, } \\
\text { EUR per pers. empl. (2009) }\end{array}$ & 1.9 & $19 \%$ & 27 & 32 & $30 \%$ & $18 \%$ & $12 \%$ & $9 \%$ \\
\hline $\begin{array}{l}\text { Investment into new fixed assets, } \\
\text { EUR per inh. (2009) }\end{array}$ & 8.9 & $11 \%$ & 27 & 32 & $26 \%$ & $10 \%$ & $6 \%$ & $4 \%$ \\
\hline SME/1,000 inh. & 1 & $103 \%$ & 9 & 9 & $135 \%$ & $104 \%$ & $99 \%$ & $74 \%$ \\
\hline $\begin{array}{l}\text { Employment in agriculture, } \% \\
\text { (2010) }\end{array}$ & 0.3 & $354 \%$ & 2 & 3 & $49 \%$ & $322 \%$ & $525 \%$ & $503 \%$ \\
\hline Employment in industry, \% (2010) & 0.9 & $106 \%$ & 12 & 13 & $92 \%$ & $115 \%$ & $106 \%$ & $112 \%$ \\
\hline Employment in services, \% (2010) & 1.3 & $78 \%$ & 27 & 31 & $107 \%$ & $77 \%$ & $65 \%$ & $65 \%$ \\
\hline Unemployment rate LFS (2010) & 0.5 & $198 \%$ & 2 & 2 & $154 \%$ & $211 \%$ & $197 \%$ & $227 \%$ \\
\hline $\begin{array}{l}\text { Total road density, } \mathrm{km} / 1,000 \text { squ.km } \\
\text { (2009) }\end{array}$ & 1.6 & $64 \%$ & 20 & 20 & $200 \%$ & $32 \%$ & $78 \%$ & $60 \%$ \\
\hline Total roads per 100,000 inh. (2009) & 1.3 & $78 \%$ & 20 & 20 & $46 \%$ & $40 \%$ & $118 \%$ & $106 \%$ \\
\hline
\end{tabular}

Source: Ministarstvo Za exonomiju i Regionalni Razvoj Republike Srbije 2011; own analysis.

Table 1: Serbia and its regions (on NUTS-2 level) compared to other European countries 


\begin{tabular}{|l|c|c|c|}
\hline & $\begin{array}{c}\text { Population } \\
\text { density }\end{array}$ & $\begin{array}{c}\text { GDP per } \\
\text { capita }\end{array}$ & Unemployment \\
\hline Belgrade Region & 31 & 231 & 244 \\
\hline Vojvodina & 182 & 268 & 259 \\
\hline Šumadija \& West Serbia & 200 & 272 & 258 \\
\hline South \& East Serbia & 223 & 273 & 260 \\
\hline
\end{tabular}

Source: Ministarstvo za ekonomiju i Regionalni Razvoj Republike Srbije 2011.

Table 2: Hypothetical positioning of Serbia's regions amongst EU NUTS-2 regions

\section{Discussion and conclusion}

Serbia is characterised by large regional socio-economic disparities, but also lagging behind the EU27 as a whole. The Serbian economy has been in a very difficult situation for a significant period of time (since the beginning of the last decade of the $20^{\text {th }}$ century). The demographic and social situation is a reflection of the very serious problems that have affected Serbia's society continuously over time (reaching far into the $20^{\text {th }}$ century). In such an environment, the state was unable to deal with the existing regional inequalities, which has led to an even more difficult situation.

There are huge regional differences in employment, GDP and GDP per capita, Gross Value Added, average salary and total investment. All of Serbia is suffering from a continuous demographic ageing process with significant differences among districts and especially municipalities. This situation continues to deteriorate due to the impact of migration flows and the educational and economic structure of the Serbian population. Everything seems to be focused on large centres, where jobs, investment and production are concentrated. Peripheral areas, especially rural ones, are characterised by relatively large disinvestment, high unemployment and low investor interest.

For several decades, different governments in Serbia have compiled different policy and analytical documents pertaining to the problem of regional inequalities. However, none of these suggestions have proved to be adequate or suitable instruments for diminishing these disparities. At local or regional level, we often encounter - a lack of clear-cut entrepreneurial spirit;"9)

- a lack of expertise in capital budgeting, business planning and feasibility studies;

- insufficient knowledge of private fund raising methodologies;

- no awareness of available soft-loan and public financial resources;

- inadequate structure of skilled technicians and skilled labor;

- a lack of information and integrated, user friendly information systems;

- missuse of local resources.

\footnotetext{
9) "Sit and wait for the central government initiatives" approach.
} 
Therefore, local development cannot be left to spontaneous market forces or in the hands of what is unfortunately sometimes a misinformed, neglectful or too busy central government (Soskić \& Popović 2006, p. 1). Existing development documents attempt to provide solutions for regional inequalities in different ways providing adequate regionalisation as a framework, but still without concrete suggestions, establishing new institutional frameworks through different councils and agencies, unfortunately without visible results (Službeni glasnik RS 50-05 and 71-05 2005, Ministarstvo ŽIVotne SREdine i PROSTORNOG PlaniRanja Republike SRbije/RepubličKa agenciJa ZA PROSTORNO PLANIRANJE 2009).

Currently, the relevant ministry (Ministry of the Economy and Regional Development [Ministarstvo za ekonomiju i regionalni razvoj Republike Srbije]) is preparing a new strategic document - the National Plan for Regional Development for the period 2013-2022 which should enable Serbia and its regions to implement a new regional policy in accordance with European regional policy (MinISTARSTVO ZA EKONOMIJU I Regionalni Razvoj Republike Srbije 2011). Four main strategic objectives are defined in the Plan: place, people, production capacity and institutional framework. The main idea is to develop all the specific potentials in every single region (a place-based approach). Each region should provide input for any future development plans resulting from discussions with relevant stakeholders and actors at regional level. The National Plan will summarise all regional initiatives and connect them with state institutions and all line ministries which in the future should take greater account of the regional component of the development process.

According to the main aims of European regional policy, NUTS-2 regions should become real functional regions. (Financial aid from European funds is directed to the NUTS-2 level.) Regional disparities within the EU have been diminished through regional policy instruments. Thus, the average GDP of less developed regions has been increased from $68.5 \%$ to $72 \%$ of the EU average. However, the question remains whether these channels of financial aid to underdeveloped regions will have the expected results. There is reasonable concern that the influx of aid from EU funds to Serbia would not be channelled to underdeveloped regions, mainly because these regions do have neither sufficient human capital nor adequate administrative infrastructure to prepare appropriate project proposals and to manage their implementation. In order to overcome this scenario, Serbia should strengthen the planning capacity of its regions and institutions on the NUTS-2 level. Each region has different needs and plans and should be able to decide which concrete needs and projects should be financed. A bottom-up approach and modern regional policy can only be implemented through strong regional institutions and regional awareness well coordinated on both levels: (a) inside the regions, between districts and municipalities and (b) together with other regions.

Regionalisation should be regarded as an instrument for a successful decentralisation of Serbia based on the principles of regional development (subsidiarity, integrity, sustainability) as well as reliable institutional infrastructure and mechanisms for regional development policy implementation. Decentralisation should increase the capacity for interaction between local economies and decision-making processes at local, national and international level. However, local development should be based on 
endogenous potential. In order to achieve that, it is necessary to identify the specific resources of each area, develop a policy for their exploitation and find ways to develop them. Optimal use of local resources could be achieved through productive and other infrastructure, business services, specific financial tools and territorial marketing.

\section{References}

Baddeley M. (2006), Convergence or Divergence? The Impacts of Globalisation on Growth and Inequality in Less Developed Countries. In: International Review of Applied Economics, 20, 3, pp. 391-410.

BARCA F. (2009), An agenda for a reformed cohesion policy, a place-based approach to meeting European Union challenges and expectations. Independent Report prepared at the request of European Commissioner for Regional Policy.

Barrios S., Strobl E. (2006), The dynamics of regional inequalities (= FEDEA Working Papers, 2006-01). Amsterdam, Elsevier.

Barro R.J., SAla-I-Martin X. (1991), Convergence across states and regions. Brookings papers on Economic Activity, pp. 107-182.

Barro R.J., S Ala-I-Martin X. (1995), Economic Growth. Singapore, McGraw-Hill.

Boldrin M., CANova F. (2001), Europe's regions: Income disparities and regional policies. In: Economic Policy, CEPR, CES, MSH, pp. 207-253.

Boschma R., Frenken K. (2011), The emerging empirics of evolutionary economic geography. Utrecht, Urban \& Regional Research Centre Utrecht, Utrecht University.

CAmagni R. (2009), Territorial Capital and Regional Development. In: CAPello R., NiJKamp P. (eds.), Handbook of Regional Growth and Development Theories, pp. 118-132. Cheltenham (UK), Edward Elgar.

Capello R. (2009), Space, growth and development. In: Capello R., Nijkamp P. (eds.), Handbook of Regional Growth and Development Theories, pp. 33-52. Cheltenham (UK), Edward Elgar.

Duro J.A. (2004), Regional Income Inequalities in Europe: An Updated Measurement and Some Decomposition Results (= Document de Treball 04.11.). Barcelona, Universitat Autònoma de Barcelona, Facultat de Ciències Econòmiques i Empresarials.

EzcurRa R. (2007), Is Income Inequality Harmful for Regional Growth? Evidence from the European Union. In: Urban Studies, 44, 10, pp. 1953-1971.

Fingleton B. (2011), The empirical performance of the New Economic Geography, with reference to small areas. In: Journal of Economic Geography, 11, pp. 267-279.

FisHER S. (2006), The New Global Economic Geography. Speech at the conference "New Economic Geography", Wyoming, Federal Reserve Bank of Kansas City.

Fujta M., Krugman P., Venables A.J. (1999), Spatial Economy: cities, regions, and international trade. Cambridge (MA), MIT Press.

Hofer H., Wörgötter A. (1997), Regional Per Capita Income Convergence in Austria. In: Regional Studies, 31, 1, pp. 1-12.

Kim S. (2008), Spatial Inequality and Economic Development: Theories, Facts, and Policies (= Working Paper, 16). Washington D.C., Commission on Growth and Development.

Krugman P. (1998), What's New about the New Economic Geography? In: Oxford Review of Economic Policy, 14, 2, pp. 7-17.

Krugman P., Livas R.E. (1996), Trade Policy and the Third World Metropolis. In: Journal of Development Economics, 49, pp. 137-150. 
LucAs R. (1988), On the Mechanics of Economic Development. In: Journal of Monetary Economics, 22, pp. 3-42.

Magrini S. (1999), The evolution of income disparities among the regions of the European Union. In: Regional Science and Urban Economics, 29, pp. 257-281.

McCANn P., VAN OORT F. (2009), Theories of agglomeration and regional economic growth: a historical review. In: CAPELlo R., NiJKamp P. (eds.) (2009), Handbook of Regional Growth and Development Theories, pp. 19-32. Cheltenham (UK), Edward Elgar.

Minailović K. (1990), Regionalna stvarnost Jugoslavije, Ekonomika [Regional realities of Yugoslavia. Economics]. Beograd.

Ministarstvo za ekonomiju i Regionalni Razvoj Republike Srbije (2011), Nacionalni plan regionalnog razvoja u Srbiji 2013-2022 - Nacrt [National plan for regional development in Serbia 2013-2022 - Draft]. Beograd.

Ministarstvo Životne sRedine i prostornog planiranja Republike Srbije/RepubličKa agencija ZA PROSTORNO PLANIRANJE (2009), Strategija prostornog razvoja Republike Srbije 20092013-2020 [Spatial development strategy for the Republic of Serbia 2009-2013-2020]. Beograd.

Ocić Č. (1998), Ekonomika regionalnog razvoja Jugoslavije, Ekonomika [Economics of regional development of Yugoslavia, Economics], Beograd.

OECD (2009), Regions Matter: Economic Recovery, Innovation and Sustainable Growth. Paris.

Petrakos G. (2001), Patterns of Regional Inequality in Transition Economies. In: European Planning Studies, 9, 3, pp. 359-383.

Petrakos G., Saratsis Y. (2000), Regional inequalities in Greece. In: Papers in Regional Science, 79, pp. 57-74.

Pike A., Rodriguez-Pose A., Tomaney J. (2006), Local and Regional Development. New York, Routlege.

RePUbličKi ZAVOD ZA RAZvoj (2009), Regionalni razvoj Srbije 2009 [Regional development of Serbia 2009]. Beograd.

REPUBLIČKI ZAVOD ZA RAZvoJ (2010), Izveštaj o razvoju Srbije 2009 [The development report of the Republic of Serbia 2009]. Beograd.

Rodrigues-Oreggia E. (2005), Regional disparities and determinants of growth in Mexico. In: The Annals of Regional Science, 39, pp. 207-220.

Romer M.P. (1986), Increasing Returns and Long-Run Growth. In: The Journal of Political Economy, 94, 5, pp. 1002-1037.

Službeni glasnik RS 50-05 i 71-05 (2005), Strateija regionalnog razvoja Republike Srbije za period od 2007. do 2012. godine [Strategy of regional development of the Republic of Serbia 2007-2012]. Beograd.

Službeni glasnik RS 79-05 (2005), Zakon o državnoj upravi [The law on state administration]. Beograd.

Službeni glasnik RS 129-07 (2007), Zakon o teritorijalnoj organizaciji Republike Srbije [The law on territorial organisation of the Republic of Serbia]. Beograd.

Službeni glasnik RS 51-09 (2009), Zakon o regionalnom razvoju Republike Srbije [The law on regional development of the Republic of Serbia]. Beograd.

Službeni glasnik RS 69-11 (2011), Uredba o utvrđivanju jedinstvene liste razvijenosti regionalnih jedinica lokalne samouprave za 2011. godinu [Regulation of regional units of local government list determination for 2011]. Beograd.

Soskić D., Popović S. (2006), Institutional instruments for promoting and managing Local Development. Belgrade, Local Development Agencies, UN-HABITAT Seminar on Integrated Local Development. 
StatističKi zavod Republike Srbije (2011a), Bulletin no 540: 2011 Census of population, households and dwellings in the Republic of Serbia. Belgrade.

StatističKi Zavod Republike Srbije (2011b), Statistical Yearbook of the Republic of Serbia. Belgrade.

StatističKi zavod Republike Srbije (2012), Opštine i regioni u Republici Srbiji 2011 [The municipalities and regions in the Republic of Serbia 2011]. Beograd.

Stimson R., Stough R.R., Nijkamp P. (2011), Endogenous Regional Development: Perspectives, Measurement and Empirical Investigation. Cheltenham, Edward Elgar.

Terrasi M. (1999), Convergence and divergence across Italian regions. In: The Annals of Regional Science, 33, pp. 491-510.

Venables J.A. (2011), Productivity in cities: self-selection and sorting. In: Journal of Economic Geography, 11, pp. 241-251.

WANG C., GE Z. (2004), Convergence and transition auspice of Chinese regional growth. In: The Annals of Regional Science, 38, pp. 727-739.

Williamson J.G. (1965), Regional inequality and the process of national development: A description of the patterns. In: Economic Development and Cultural Change, 13, 2, pp. 3-84.

Yemtsov R. (2003), Quo Vadis? Inequality and Poverty Dynamics across Russian Regions (= Discussion Paper, 2003/67). Helsinki, World Institute for Economic Development Research. 